\section{"ON THE POSITION OF SHIP SURGEONS."}

To the Editor of THE LANCET.

SrR,-I quite agree with some of the difficulties mentioned in Dr. Irwin's letter of the 17th inst., with which a ship surgeon has to contend, and I think there is another diff. culty which might be added to Dr. Irwin's list, and this is, the unpleasantness the ship surgeon often meets with, when doing his duty, in laying-up some of the crew. Accidents happen in smooth as well as in rough weather, and there is always a certain amount of rheumatism and bronchitis (according to the weather); these cases, of course, tend to diminish the number of the "watch." The cases I am about to mention are those of sprains, onychia, buboes, orchitis, aneurisms, and other ailments, about which the doctor is frequently consulted very often after having only been a few days at sea. If the surgeon by any chance "is not in with" the captaiu it is a difficult, and by no means a pleasant task to perform in "layiug up" these cases, for at the best of times it is not always an easy matter to convince the public of the importance of absolute rest, especially in the present case, when the "watch" suffers in consequence. What $I$ would like to suggest is this: if the crew before "signing on" were submitted to a proper medical inspection, many of these cases would be diagnosel, and prevented from sailing; also, if any former illness was stated on the sailor's "discharge" (just as a note is made of his conduct), this would greatly help in the selection of a fit crew, and in a great measure prevent the unpleasantness of which I speak. This would not ans wer in every case, for sailors are fre quently changing from ships withont surgeons to passenge ships, but if an inspection was made any present ailment would be detected previous to fresh "signing on." I have made several trips in the following lanes: Orient, White Star, Allan, Pacific, National, and Money IVigrams, sometimes as a passenger, and at other times as the surgeon, so $\mathrm{mv}$ experience has not been gathered from one line of ships alone. Yours faithfully,

G. C. HARDiNG, L.R.C.P.ED., \&c.

Westgate-on-Sea, Dec. 22nd, 1881.

\section{To the Editor of THE LANCET.}

SIR,-In last week's issue of THE LANCET you publish an excellent letter on the above subject by Dr. Irwin. I entirely endorse his remarks. Having been for nearly six years acting in the capacity of surgeon on board various passenger steamers of different Atlantic companies, I feel qualified to give an opinion. The life is no doubt a pleasant one-at least, during the summer months-but the responsibility is great. Ia one of my voyages I had charge of 1700 emigrants, and during the voyage there were 143 cases of scarlet fever, four of which proved fatal. I had an assistant, it is true; but what was he? An elderly man, who in his younger dxys had been for a few months in a druggist's shop, and since then had gained a precarious livelihiod by singing in "salonns," \&e., or assisted by his few friends, who had at last managed to get him a berth as assintantsurgeon on a passenger steamer. He was got cheap, that's the secret. His salary was $\mathfrak{f} 4$ per month. The pay is not the only indignity heaped upon the surgeon; he is looked upon as a compulsory nuisance, a sort of "Pimsoll's mark," by all the ship's crew, and uuless he happens to get in with the captain, he will be suubbed by all hands. As one of many examples which I know of, where the captain's displeasure was incurred, I mention the fullowing:--One captain was of a jealous disposition, and very conceited (a malady common amongst that genus), and did not like passengers to pay attention to any but himself; and because I happened to gain more respect than he did, he must have his revenoe, which was to order the light in my miserable cabin to be put out at 9 P.M., so that I could not read. I told him I would report his conduct, but he laughed at the idea, he being a shareholder in the company. Such is only one of many indinnities I conld mention. "To get good men to stay in the flodting emigration service, the pay must be raised; this is very necessary, as the dangers are great and insurance is high. The surgeon should be put in an entirely independent position; the same, for exumple, as the old mail masters in the Cunard service. His name should not be on the ship's "articles." He should keep a separate "log," giving a daily account of all duties connected with his department, which should be given to the emigration officials when he arrives at home, they, and they alone, being bis masters. The very fact that men of education are compelled to be in such close companionship with the captains, the majority of whom are very illiterate, is sufficiently repagnant, without, being at their besk and call, as their fancies dictate. Dec, 1881.

I am, Sir, yours, \&c. AN Old ShIP SURgeon.

\section{To the Editor of THE LANCET.}

SrR, - I served for over eight years as surgeon in steamers running between Liverpool and New York belonging to a well-known Company, and during the last half of my time was actually in receipt of less pay than when I first went to sea. During the time I speak of I was in medical charge of over fifty thousand souls. In my opinion the surgeon of an emigrant ship ought to be a Government official, paid by Governmeat and responsible to Government. When the company or owners of a steamer select a surgeon, they send him to the Government Emigration Office, who supply him with a printed paper of which I give a copy, suppressing names :-

"Government Emigration Office.

"I appoint A. B- to take medical charge of the steamship $C D$, he being qualified by the 42 ud section of the Passengers Act for 1855, and Passengers Act Amendment Act, 1863.

"E. F., Emigration Olficer."

"It is desirable that surgeons in charge of passenger ships should keep a recird of any sickness that occurs on the voyage, together with the treatment and result of the same; a report of which should be sent to this office at the end of the voyage, prepaid, addressed - 'Oa her Majesty's Service : The Emigration Officer."

This modest request for a report was not appended to the appointment wheu I first went to sea, but was made about four years afterwards, and is altogether gratuitous, no fee being given for it. The aip pointment has to be renewed each voyage, and that is all the result arising from the surgeon's introduction to the Emigration authorities. I never knew of a surgeon making any complaint to the emigration people about overcrowding, defective ventilation, or any other shortcomings on the part of the owners. If any such complaint were marde, the result would be, I imagine, as follows-instant dismi-sal of the surgeon by the owners of the steam-ship, and a verdict by the emigration authorities of "Serve him right."

Dec. 23rd, 1881.

$$
\text { I am, Sir, your obedient servant, }
$$
MERCaNTile Marine.

\section{SEA-SICKNESS.}

To the Editor of THE LANCET.

SIR,-In answer to Dr. Irwin's invitation, I venture, having had twelve munths' experience in the observation of sea-sickness, to offer the following criticism.

The semicircular canals are so placed that their contents are influenced by up-and-down movements, least in the erect, and most in the recumbent, posture. In the latter vomiting ceases whether the face be turned up or down. The swing-like motion of a ship induces an automatic rbythmical action of the nerve ceutres concerned in the active movements of the body, and in the appreciation of the movements of objects in view. This is proved by the fact that this rhythmical action continues when all movements have ceased, so that stationary objects seem to move up and down before the eyes, and the ground seems to undulate beneath the feet. Rhylhmicrl action is also probably induced in the vaso-motor centres; for the bloodve-sel; resemble elastic tubes distended with fluid, and these, when subjected to a seesy motion. elongate and shorten, expand and contract, under the influence of their contained fluid. If the bloodvessels are affected in the same manner, it becomes highly probable that the vaso-motor centres take on a rbythmical action to counteract it. Violent sickness sometimes occurs after landiug, even when no vomiting has taken ylace at sea. This cannot be due to the now stationary endolymph and otoliths, but may be explained by the $f_{d} c t$ that the automatic rbythmical action of the nervecentres continues. Vomiting may occur even 